\title{
ANALISIS SPASIAL PERSEBARAN REKLAME
}

\author{
Gunanto $^{1)}$, Dhomas Hatta Fudholi ${ }^{2)}$ dan Lizda Iswari ${ }^{3)}$ \\ ${ }^{1}$ Universitas Islam Indonesia \\ email: 1391724@students.uii.ac.id \\ ${ }^{2}$ Fakultas Teknologi Industri, Universitas Islam Indonesia \\ emapkdil: hatta.fudholi@uii.ac.id \\ ${ }^{3}$ Fakultas Teknologi Industri, Universitas Islam Indonesia \\ email: lizda.iswari@uii.ac.id
}

\begin{abstract}
Regional autonomy is the surrender of authority from the center to the regions to regulate and manage the interests of the local community according to their own initiatives based on the aspirations of the people, as stated in Law No. 32 of 2004 concerning Regional Government. With the existence of regional autonomy, the regional government is expected to be better to explore the potential of local revenue sources in financing all regional development activities through increasing Original Local Government Revenue (OLGR). One component of OLGL that has a contribution in Pekalongan Regency is Regional Tax. Regional tax, one of which is advertisement tax, is one component of the OLGL that contributes to regional development. Clustering algorithm, one of which is k-means clustering can be applied to advertisement tax data so that it can be known that ad grouping is based on distance from the market, distance to traffic light and vehicle volume. From each of these groupings can also be seen each of the characteristics so that it is known which groups have the largest amount of tax and the number of tax donations. From this research, a webbased system has been successfully developed that is able to process the spatial analysis of the distribution of billboards with the clustering method in Pekalongan Regency. From the results of clustering analysis, it can be seen that the Subdistrict passed by the coastline has a correlation with the high amount of advertisement tax in Pekalongan Regency, this can be seen in the results of clustering using the k-means algorithm, where advertisements are in clusters that have average quantities the highest taxes are all in the sub-district that is crossed by north coast way. The closeness to the market and traffic light has a correlation with the high amount of billboard bill advertising tax in Pekalongan Regency, wherein the clusters that have the highest volume of vehicles the average size of the billboard tax is high.
\end{abstract}

Keywords: clustering, spatial analysis, $k$-means, advertisement tax, OLGR

\section{PENDAHULUAN}

Undang - Undang No. 32 tahun 2004 tentang Pemerintah Daerah menyebutkan bahwa otonomi daerah merupakan penyerahan kewenangan dari pusat kepada daerah untuk mengatur dan mengurus kepentingan masyarakat setempat menurut prakarsa sendiri berdasarkan aspirasi rakyat [1]. Dengan adanya otonomi daerah, pemerintah daerah diharapkan untuk lebih mampu menggali potensi sumber-sumber penerimaan daerah dalam membiayai segala aktivitas pembangunan daerah melalui peningkatan Pendapatan Asli Daerah (PAD) yang salah satunya adalah pajak reklame.[2]

Realisasi pajak reklame di Kabupaten Pekalongan dari tahun ke tahun selalu mengalami peningkatan (BPKD Kabupten
Pekalongan, 2018) [3], sehingga semakin banyak potensi pajak reklame yang harus dikelola. Semakin banyaknya potensi reklame yang harus dikelola, maka diperlukan sebuah analisis untuk monitoring persebaran potensi reklame yang ada di Kabupaten Pekalongan [4].

Analisis spasial digunakan pada beberapa studi dan telah terbukti efektif untuk mendapatkan gambaran tentang sebuah fenomena spasial. Beberapa studi terkait adalah penelitian yang dilakukan oleh [5], pada penelitiannya analisis spasial digunakan untuk melihat keterkaitan secara spasial dalam penyebaran DBD (Demam Berdarah Dengue). Penelitian lain yang dilakukan [6], membahas tentang analisis sebaran reklame billboard terhadap lokasi dan nilai pajak 
reklame, serta analisis evaluasi tatanan reklame billboard berbasis Sistem Informasi Geografi (SIG). [7] dalam penelitiannya membahas tentang analisis spasial sebaran kasus tuberculosis paru ditinjau dari faktor lingkungan dalam dan luar rumah di Kabupaten Pekalongan.

Tujuan yang ingin dicapai dari penelitian ini adalah mengetahui analisis spasial persebaran reklame dengan k-means clustering yang berada di Kabupaten Pekalongan berdasarkan jarak dengan pasar, jarak dengan traffic light dan volume kendaraan. Metode cluster k-means mengidentifikasi objek yang memiliki kesamaan karakteristik tertentu, dan kemudian menggunakan karakteristik tersebut sebagai centroid [8]

Dari hasil analisis dapat dilihat masingmasing karakteristiknya sehingga diketahui kelompok mana yang memiliki besaran sumbangan pajak dalam jumlah yang paling banyak dan sedikit. Selain itu, hasil analisis mampu memberikan rekomendasi bagi pemerintah daerah dalam pengambilan kebijakan terkait pengelolaan pajak reklame di Kabupaten Pekalongan.

\section{KAJIAN LITERATUR}

Penelitian terkait analisis spasial telah banyak dilakukan, diantaranya adalah penelitian yang pernah dilakukan oleh [5] penelitiannya membahas tentang analisis spasial sebaran DBD di Kota Tasikmalaya tahun (2011-2015). Pada penelitiannya, peneliti membuat sebuah aplikasi untuk mengolah data dengan melibatkan pembuatan peta. Pengumpulan data dilakukan dengan membuat titik (plotting) rumah dan lingkungan penderita DBD berbantukan Global Positioning System (GPS). Analisis spasial digunakan untuk melihat keterkaitan secara spasial dalam penyebaran DBD (Demam Berdarah Dengue). Keterkaitan secara spasial dalam penyebaran DBD diukur melalui korelasi spasial dengan menggunakan indeks moran. Disamping itu dalam menjelaskan pola persebarannya digunakan Nearest Neighbour Analysis (NNA).

[6] membahas tentang analisis sebaran reklame billboard terhadap lokasi dan nilai pajak reklame, serta analisis evaluasi tatanan reklame billboard berbasis SIG. Dalam penelitian ini dihasilkan pula sebuah prediksi potensi reklame billboard baru dengan melakukan buffer.

Penelitian yang dilakukan [9] membahas tentang analisis clustering menggunakan metode $k$-means dalam pengelompokkan penjualan produk pada swalayan Fadhila. Penelitian ini mengelompokkan data menjadi laris dan kurang laris. Hasil yang dicari secara manual eqiuvalen dengan hasil yang diproses dengan nonmanual. Penelitian lain terkait clustering k-means yang dilakukan oleh [10] membahas tentang analisis cluster dengan algoritma $k$-means dan fuzzy c-means clustering untuk pengelompokan data obligasi korporasi yang hasilnya adalah cluster 7 merupakan cluster yang terbaik karena cluster 7 memuat obligasi dengan rating $\mathrm{AA}+$ dan AAA dengan time to maturity yang tidak terlalu lama

Berbeda dengan penelitian-penelitian sebelumnya, penelitian yang dipaparkan pada makalah ini mengangkat analisis spasial persebaran reklame dengan menggunakan metode clustering $k$-means. Penggunaan clustering $k$-means dengan data spasial masih jarang dilakukan, terutama pada data persebaran reklame. Berikut ini beberapa hal yang membedakan penelitian yang dilakukan dengan penelitian-penelitian sebelumnya :

a. Penelitian ini mengambil lokasi di Kabupaten Pekalongan.

b. Penelitian ini menggunakan tiga variabel spasial yaitu jarak dengan pasar, jarak dengan traffic light, dan volume kendaaran.

c. Penelitian ini mengembangkan sebuah aplikasi SIG untuk membantu analisis spasial persebaran reklamenya.

\section{METODE PENELITIAN}

\section{A. Lokasi Penelitian}

Lokasi Penelitian dilakukan di Kabupaten Pekalongan yang merupakan salah satu bagian dari wilayah Provinsi Jawa Tengah, terletak diantara $109^{\circ}-109^{\circ} 78^{\prime}$ Bujur Timur dan $6^{\circ}-7^{\circ} 23^{\prime}$ Lintang Selatan. Luas wilayah keseluruhan adalah $\pm 836,13 \mathrm{~km}^{2}$. Kabupaten ini terbagi menjadi 19 Kecamatan, yang meliputi 272 Desa dan 13 Kelurahan. Kabupaten Pekalongan berbatasan dengan Kota Pekalongan dan Laut Jawa disebelah Utara, Kabupaten Banjarnegara disebelah Selatan, Kota Pekalongan dan Kabupaten 
Batang disebelah Timur, serta Kabupaten Pemalang disebelah Barat.

\section{B. Jenis Data}

Terdapat dua jenis data yang digunakan dalam penelitian ini: data spasial dan data non spasial. Kedua jenis data ini akan dipaparkan sebagai berikut.

Data spasial adalah gambaran nyata suatu wilayah yang terdapat di permukaan bumi. Data spasial pada umumnya direpresentasikan berupa grafik, peta, gambar dengan format digital dan disimpan dalam bentuk koordinat $\mathrm{x}, \mathrm{y}$ (vektor) atau dalam bentuk image (raster) yang memiliki nilai tertentu. Data koordinat dan peta didapatan dari aplikasi SIG yang dibangun menggunakan bahasa pemrograman PHP dan basis data MySQL. Aplikasi ini terhubung dengan Google Maps API.

Data non spasial adalah data berbentuk tabel yang berisi informasi yang dimiliki oleh obyek data spasial. Data tersebut berbentuk data tabular yang saling terintegrasi dengan data spasial yang ada. Untuk data non spasial seperti data reklame, kawasan jalan, dan kelas wilayah didapat dari studi lapangan. Hal ini dilakukan dengan mengambil informasi dari database SIAPADA (Sistem Informasi Administrasi Pajak Daerah) di Badan Pengelolaan Keuangan Daerah (BPKD) Kabupaten Pekalongan. Sedangkan untuk data pasar diambil dari Dinperindagkop dan UKM. Data tingkat keramaian pengguna jalan diambil dari data survei CTMC (Classified Turning Movement Counting) pada Buku Kinerja Keselamatan Transportasi Jalan di Kabupaten Pekalongan [6].

\section{Pengumpulan Data}

Penelitian ini dilakukan dengan mengumpulkan data pajak reklame dari basisdata pembayaran pajak pada BPKD Kabupaten Pekalongan. Dari basisdata tersebut dilakukan proses extract, transform, load (ETL) menuju basisdata aplikasi SIG yang nantinya dijadikan sebagai bahan analisis. Untuk kebutuhan analisis, ada datadata lain yang perlu dimasukkan ke dalam basisdata, diantaranya adalah data koordinat reklame, data pasar beserta koordinatnya, data traffic light beserta koordinatnya, data kawasan jalan, data kelas wilayah dan data volume kendaraan

\section{Tahapan Penelitian}

Penelitian yang dilakukan mempunyai 10 tahapan yang ditunjukkan pada gambar 3.1. Tahapan-tahapan tersebut dipaparkan sebagai berikut.

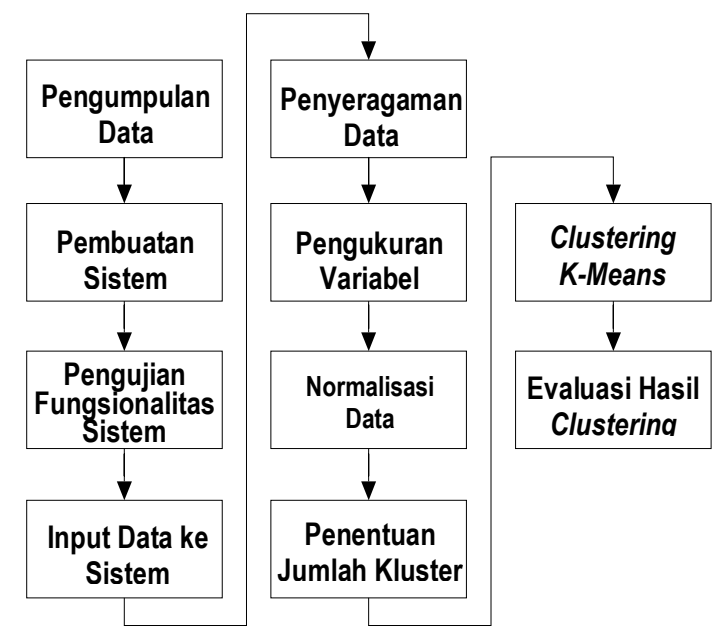

Gambar 3.1 Tahapan Penelitian

\section{Pengumpulan Data}

Tahapan ini merupakan tahapan pengumpulan data-data pajak reklame, serta data-data lain terkait penelitian untuk dijadikan sebagai bahan analisis.

2. Pembuatan Sistem

Tahapan ini merupakan pembangunan aplikasi SIG yang ditujukan untuk membantu dalam proses penelitian, serta meyajikan hasil clustering yang nantinya dapat digunakan oleh pemerintah daerah dalam pengambilan kebijakan terkait pengelolaan pajak reklame.

3. Pengujian Fungsional Sistem

Pengujian fungsional dilakukan untuk memastikan sistem bebas dari kesalahan. Pengujian sistem dilakukan dengan metode black box dengan melibatkan petugas pengelola pajak reklame BPKD Kabupaten Pekalongan.

\section{Input Data ke Sistem}

Tahapan ini dimaksudkan untuk memasukkan data-data penelitian ke dalam aplikasi SIG.

\section{Penyeragaman Data}

Penyeragaman data dilakukan dengan memberikan kode (seperti kode kecamatan, kode kelas wilayah, dan kode kawasan jalan) untuk proses analisis. Kode disini adalah kode-kode yang tidak ada dalam data yang telah diambil dari basisdata pada aplikasi SIAPADA. 


\section{Pengukuran Variabel}

Pengukuran variabel adalah proses pemberian nilai atau atribut pada suatu objek. Variabel yang digunakan pada penelitian ini adalah variabel jarak dengan pasar, jarak dengan traffic light, dan volume kendaraan

7. Normalisasi Data

Data analisis yang diperoleh tidak terdistribusi dengan normal dan perlu dilakukan normalisasi data.

\section{Penentuan Jumlah Cluster}

Proses clustering dengan menggunakan algoritma $k$-means bergantung pada jumlah cluster awal. Jika jumlah cluster yang ditentukan tidak optimal maka hasil cluster juga tidak akan sesuai dengan yang diharapkan. Untuk menentukan jumlah cluster yang optimal, penelitian ini menggunakan library NBClust pada RStudio dengan menggunakan semua indeks yang ada.

\section{Clustering $K$-means}

Algoritma k-means merupakan algoritma yang relatif sederhana untuk mengelompokkan sejumlah besar obyek dengan atribut tertentu ke dalam kelompokkelompok (cluster) sebanyak K. Pada algoritma k-means, jumlah cluster $\mathrm{K}$ sudah ditentukan lebih dahulu.

Setiap cluster memiliki titik pusat dan anggota-anggota dari satu cluster dipilih berdasarkan jarak dari titik pusat cluster terdekat. Penentuan keanggotaan dan titik pusat cluster tidaklah mudah, karena penambahan satu anggota pada lokasi yang signifikan akan merubah lokasi titik pusat cluster, dan status keanggotaan harus ditinjau kembali. Perubahan keanggotaan akan kembali merubah lokasi titik pusat dan seterusnya. Keanggotaan dimungkinkan akan berubah lagi. Oleh karena itu, proses penentuan titik pusat dan keanggotaan cluster harus dilakukan dalam iterasi (perulangan) hingga posisi titik pusat dan angota-anggota cluster benar-benar stabil. Perhitungan clustering k-means mengikuti rumusan di [10].

\section{Evaluasi Hasil Clustering}

Tahapan ini membahas dan menganalisis hasil clustering yang telah dilakukan, serta penyampaian rekomendasi terkait hasil analisis.

\section{HASIL DAN PEMBAHASAN}

Penelitian ini dimulai dengan pembangunan sistem terlebih dahulu untuk membantu proses penelitian. Sistem membantu dalam melakukan pengumpulan data (terutama data spasial), penyeragaman data, dan melakukan proses clustering serta menyajikan hasil clustering kedalam peta spasial. Hasil dan pembahasan dalam penelitian ini dapat dijelaskan kemudian.

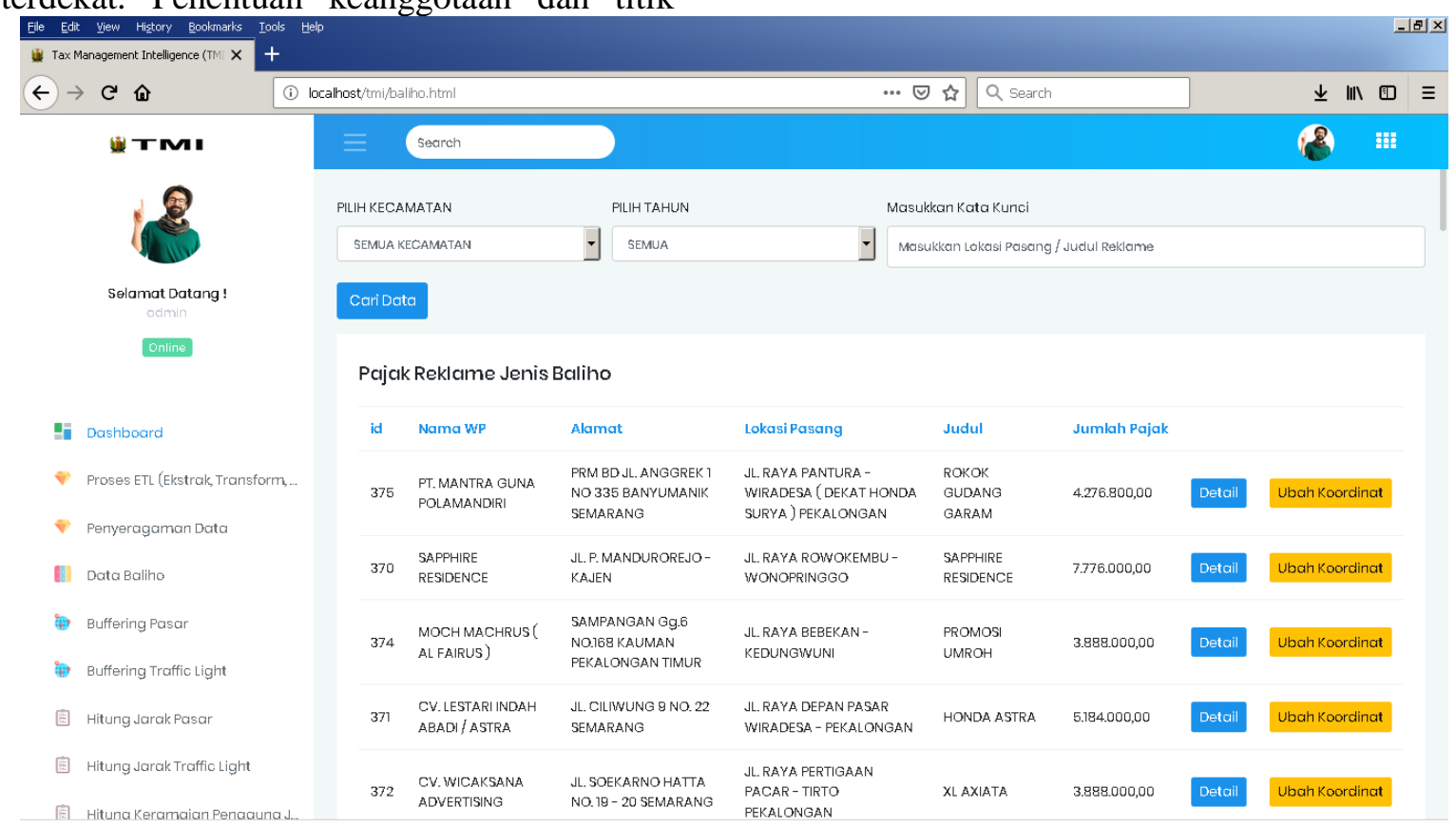

Gambar 4.1 Tampilan Aplikasi SIG 


\section{A. Pengembangan Sistem}

Sistem yang dibangun bertujuan untuk dapat memvisualisasikan data dan informasi kepada pengguna sistem, dimana dalam pembuatannya diselaraskan dengan kebutuhan pengguna. Pada tahapan pengembangan sistem ini merupakan aktivitas pemrograman, dimana aplikasi yang dibangun adalah aplikasi SIG berbasis web. Aplikasi SIG dikembangkan untuk membantu dalam proses penelitian, yang diantaranya adalah melakukan proses ETL, melakukan penyeragaman data, pengukuran variabel, dan melakukan clustering k-means. Gambar 4.1 menunjukkan tampilan aplikasi SIG yang telah dikembangkan.

\section{B. Pengujian Fungsional Sistem}

Aplikasi yang dikembangkan harus dipastikan bebas dari kesalahan karenanya perlu dilakukan proses pengujian fungsional terhadap sistem yang telah dikembangkan. Pengujian sistem dilakukan dengan metode black box dengan melibatkan petugas pengelola pajak reklame BPKD Kabupaten Pekalongan. Tabel 4.1 menunjukkan skenario pengujian sistem dengan metode black box testing.

Tabel 4.1. Skenario pengujian dengan Black Box Testing

\begin{tabular}{|c|c|c|c|}
\hline No & Skenario pengujian & Hasil yang diharapkan & $\begin{array}{c}\text { Hasil } \\
\text { pengujian }\end{array}$ \\
\hline 1 & \begin{tabular}{|l|} 
Menjalankan proses Ektraksi \\
Basis Data dengan \\
menghubungkannya dengan \\
database sumber (database \\
SIAPADA) kemudian \\
memasukkan informasi koneksi \\
database kemudian menekan \\
button pilih koneksi \\
\end{tabular} & $\begin{array}{l}\text { Sistem dihubungkan dengan } \\
\text { database SIAPADA } \\
\text { menampilkan status aktif dan } \\
\text { berubah menjadi warna hijau } \\
\text { pada status koneksi. Ketika } \\
\text { koneksi tidak berhasil, } \\
\text { menampilkan message box } \\
\text { "Koneksi anda salah" } \\
\end{array}$ & Sesuai \\
\hline 2 & $\begin{array}{l}\text { Pengguna melakukan login pada } \\
\text { sistem informasi sesuai dengan } \\
\text { username yang sudah didaftarkan } \\
\text { administrator }\end{array}$ & \begin{tabular}{|l|} 
Sistem melakukan validasi \\
terhadap proses login, untuk \\
masuk pada halaman utama \\
aplikasi.
\end{tabular} & Sesuai \\
\hline 3 & $\begin{array}{l}\text { Pengguna masuk ke dalam } \\
\text { aplikasi, memasuki semua } \\
\text { halaman, dan melihat beberapa } \\
\text { chart di dalamnya. }\end{array}$ & $\begin{array}{l}\text { Sistem menampilkan } \\
\text { informasi sesuai dengan } \\
\text { yang dipilih pengguna dalam } \\
\text { bentuk visual (chart). }\end{array}$ & Sesuai \\
\hline 4 & $\begin{array}{l}\text { Pengguna memasuki menu - } \\
\text { menu scoring yaitu dengan } \\
\text { memilih menu scoring sesuai } \\
\text { variabel yang dikehendaki }\end{array}$ & $\begin{array}{l}\text { Sistem menampilkan hasil } \\
\text { scoring terhadap variabel - } \\
\text { variabel yang terpilih }\end{array}$ & Sesuai \\
\hline 5 & $\begin{array}{l}\text { Pengguna memasuki halaman } \\
\text { peta persebaran reklame dengan } \\
\text { memilih menu peta persebaran } \\
\text { reklame }\end{array}$ & $\begin{array}{l}\text { Sistem menampilkan titik - } \\
\text { titik reklame yang berada } \\
\text { pada wilayah Kabupaten } \\
\text { Pekalongan }\end{array}$ & Sesuai \\
\hline 6 & $\begin{array}{l}\text { Pengguna memasuki halaman } \\
\text { Cluster K-means dengan } \\
\text { memasukkan jumlah cluster }\end{array}$ & $\begin{array}{l}\text { Sistem melakukan proses } \\
\text { penyimpanan data cluster } \\
\text { kemudian menampilkan } \\
\text { kembali hasil inputan }\end{array}$ & Sesuai \\
\hline 7 & $\begin{array}{l}\text { Pengguna memasuki halaman } \\
\text { Cluser K-means dengan } \\
\text { memasukkan data cluster dalam } \\
\text { format excel }\end{array}$ & $\begin{array}{l}\text { Sistem melakukan import } \\
\text { data excel ke dalam sister } \\
\text { dan menampilkan data hasil } \\
\text { import }\end{array}$ & Sesuai \\
\hline 8 & $\begin{array}{l}\text { Pengguna memasuki halaman } \\
\text { Cluster K-means dengan } \\
\text { melakukan proses Clustering }\end{array}$ & $\begin{array}{l}\text { Sistem melakukan proses } \\
\text { clustering dan menampilkan } \\
\text { hasil clustering }\end{array}$ & Sesuai \\
\hline
\end{tabular}

Skenario pengujian dengan black box testing digunakan untuk mengamati kesesuaian dari skenario pengujian dengan hasil yang diharapkan. Terlihat pada tabel 4.1, bahwa dari 8 (delapan) pengujian menunjukkan hasil yang sesuai.

\section{Pengumpulan Data}

Dalam penelitian ini penulis menggunakan data pembayaran pajak reklame tahun 2018. Data pembayaran pajak reklame tersebut diambil dari basisdata pada aplikasi SIAPADA (Sistem Informasi Administrasi Pajak Daerah) yang berada pada BPKD Kabupaten Pekalongan. Untuk proses pengambilan data, penulis menggunakan sistem yang dibangun untuk melakukan ekstraksi data. Setelah proses pengambilan selesai, dilakukan filter terhadap data-data yang akan dijadikan sebagai bahan analisis. Data yang digunakan pada penelitian ini adalah data reklame dengan jenis baliho yang mempunyai masa pajak lebih dari satu tahun. Pajak reklame yang masa pajaknya kurang dari satu tahun bisa jadi merupakan reklame insidentil, sehingga tidak sesuai untuk dimasukkan dalam penelitian.

\section{Penyeragaman Data}

Penyeragaman data dilakukan dengan memberikan kode untuk proses analisis. Kode ini tidak ada di dalam data yang telah diambil dari basisdata pada aplikasi SIAPADA. Kodekode tersebut adalah kode wilayah, kode kawasan dan kode kecamatan. Pemberian kode dilakukan dengan menggunakan query yang ditanamkan pada sistem. Proses pemberian kode dimulai dengan mempelajari ciri khas dari inputan pada aplikasi SIAPADA, sebagai contoh : pada aplikasi SIAPADA terdapat field lokasi, namun pada field tersebut masih belum standar dalam menyebutkan nama kecamatan. Penyebutan nama kecamatan perlu dikonversi menjadi kode agar standar. Disini peneliti mengamati beberapa penyebutan nama kecamatan dalam field lokasi yang tidak standar seperti : Wiradesa dengan wides, Karanganyar dengan krnganyar, kranyar dan lain - lain.

Penelitian ini membutuhkan data spasial untuk proses analisis, sehingga diperlukan data koordinat untuk melakukan perhitungan jarak antar variabel-variabel yang diperlukan untuk keperluan analisis. Pengambilan koordinat dilakukan dengan menggunakan layanan google maps. 


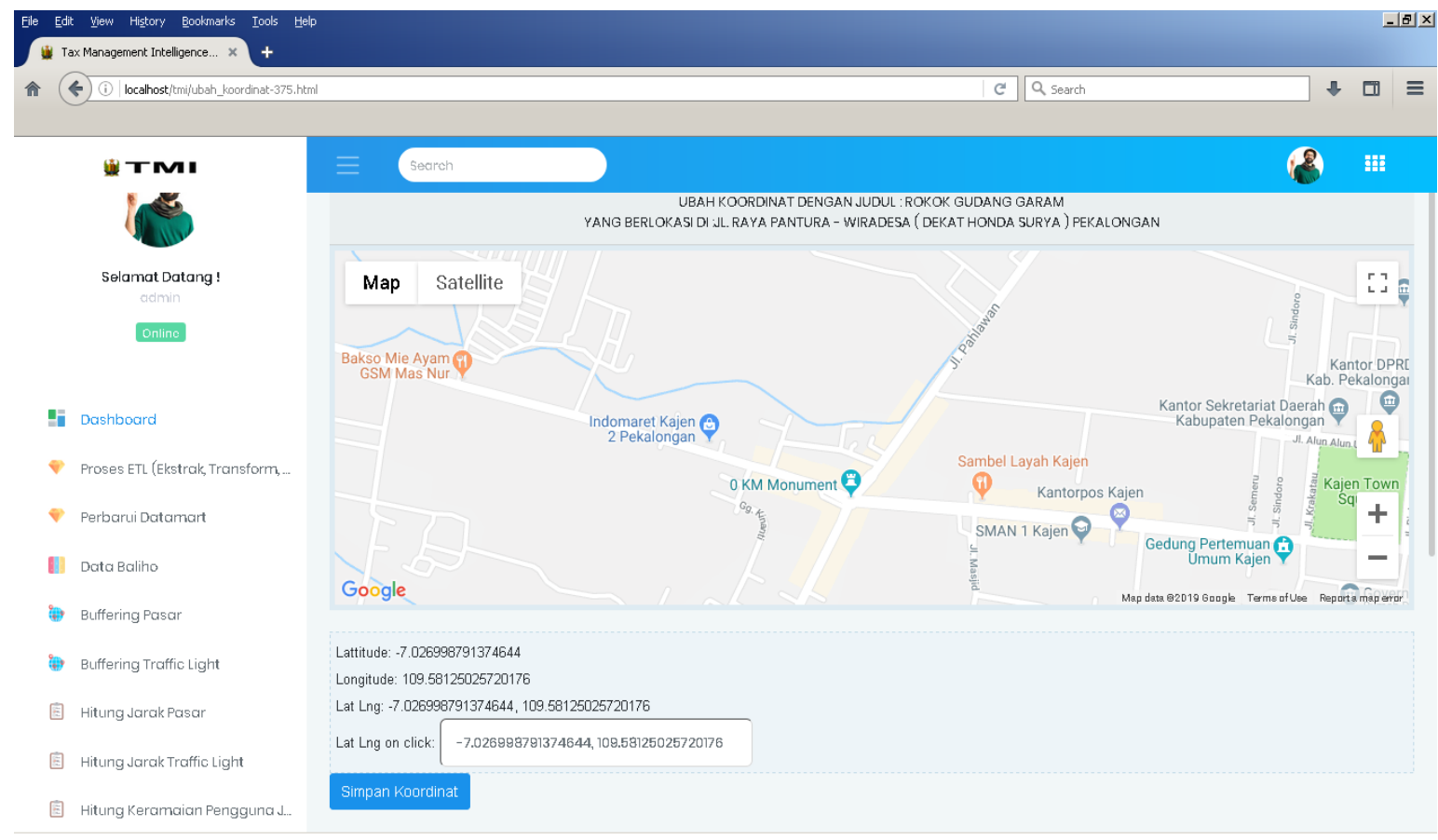

Gambar 4.2 Pengambilan Koordinat

Gambar 4.2 menunjukkan proses pengambilan koordinat untuk reklame dengan judul Rokok Gudang Garam. Proses pengambilan koordinat dilakukan melalui pencarian titik koordinat berdasarkan keterangan lokasi yang berada pada basisdata SIG, serta sesuai dengan keterangan dari petugas pemungut pajak yang menangani reklame di wilayah tersebut.

\section{E. Pengukuran Variabel}

Pengukuran variabel adalah proses pemberian nilai atau atribut pada suatu objek. Variabel yang digunakan pada penelitian ini adalah variabel jarak dengan pasar, jarak dengan traffic light, dan volume kendaraan.

Pengukuran variabel jarak dengan pasar dan jarak dengan traffic light penulis menggunakan formula haversine, sedangkan untuk pengukuran volume kendaraan digunakan data survei CTMC (Classified Turning Movement Counting) pada Buku Kinerja Keselamatan Transportasi Jalan di Kabupaten Pekalongan [6].

Gambar 4.3 menunjukkan potongan script dari pengukuran jarak reklame. Pengukuran jarak reklame dalam penelitian ini menggunakan fungsi formula haversine. Formula haversine menghasilkan jarak terpendek antara dua titik yang diambil dari garis bujur (longtitude) dan garis lintang (latitude).

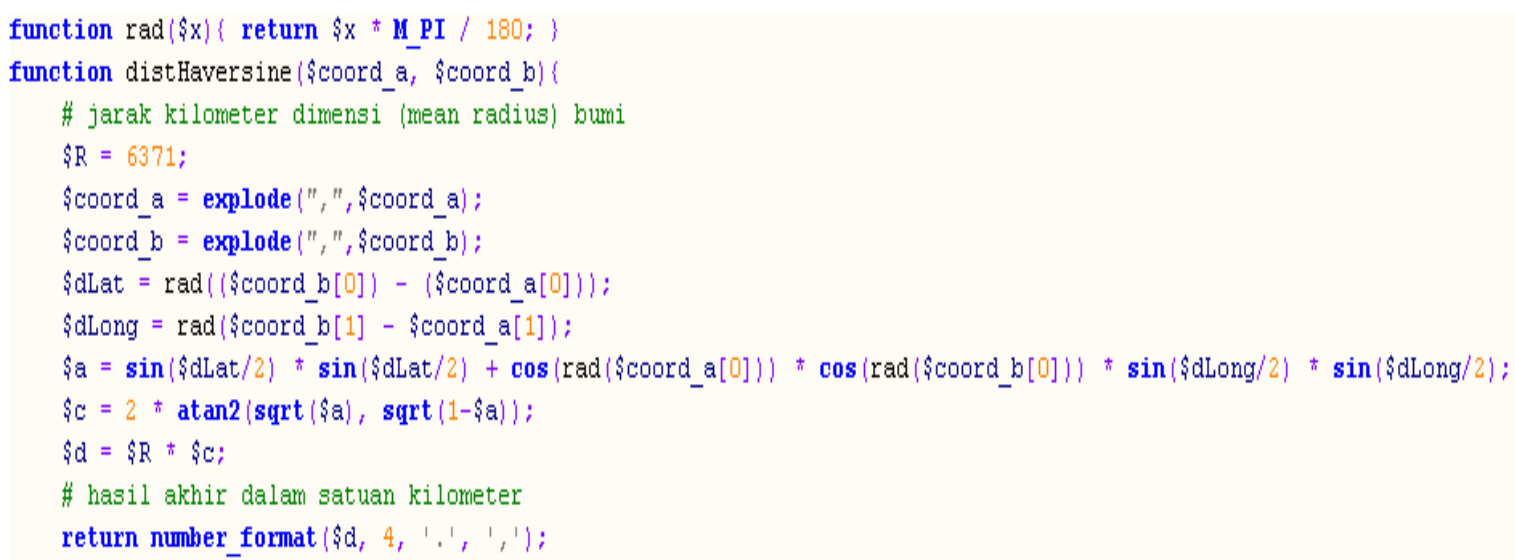

Gambar 4.3 Potongan script dari pengukuran jarak reklame 


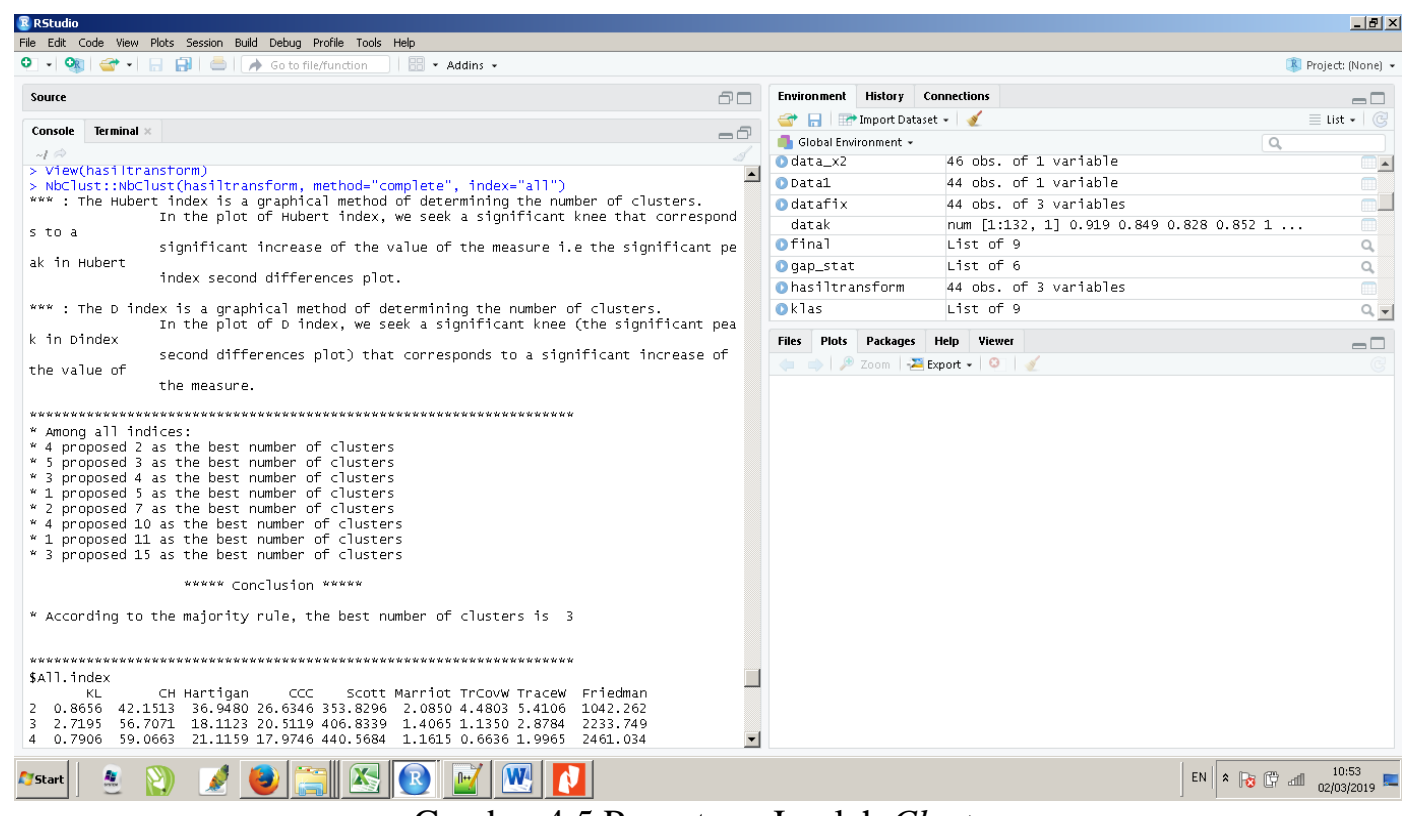

Gambar 4.5 Penentuan Jumlah Cluster

F. Normalisasi Data

Normalisasi data dilakukan dengan cleaning data terlebih dahulu. Proses cleaning dilakukan dengan membuang data-data dengan nilai yang ekstrim atau yang disebut dengan data outlier. Data pencilan atau data outlier itu muncul karena ada reklame yang muncul pada kecamatan yang tidak ada traffic lightnya sehingga pengukuran jarak reklame dipetakan dengan traffic light yang terdekat dari wilayah kecamatan dimana reklame berada. Setelah dilakukan cleaning, data diuji dengan pengujian normalitas menggunakan metode shapiro-wilk. Shapiro dan Wilk dalam Razali dan Wah (2011) menyampaikan bahwa uji shapiro-wilk merupakan uji yang paling baik untuk semua jenis distribusi dan ukuran sampel. Gambar 4.4 menunjukkan uji normalitas dengan metode sapiro wilk di RStudio.

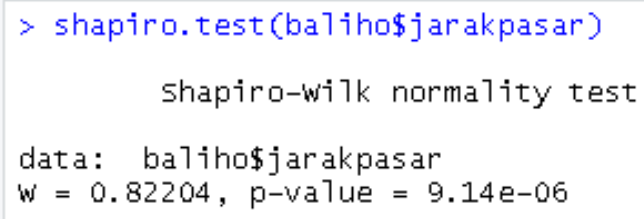

Gambar 4.4 Pengujian normalitas di RStudio

Gambar 4.4 menunjukkan pengujian normalitas menggunakan metode shapiro wilk, dari pengujian tersebut ternyata data masih belum terdistribusi secara normal, sehingga dilakukan transformasi data. Transformasi data adalah upaya yang dilakukan dengan tujuan utama untuk mengubah skala pengukuran data asli menjadi bentuk lain, sehingga data dapat memenuhi asumsi-asumsi yang mendasari analisis ragam. Untuk mengatasi ketidaknormalan data, penelitian ini menggunakan tranformasi Box-Cox.[11]

\section{G. Penentuan Jumlah Cluster}

Penentuan jumlah cluster pada penelitian ini menggunakan aplikasi RStudio. Data yang telah dinormalisasi kemudian diproses di RStudio untuk menentukan jumlah cluster yang optimal. Untuk menentukan jumlah cluster yang optimal, penelitian ini menggunakan library NBClust pada RStudio dengan menggunakan semua indeks yang ada.[12]

Berdasarkan gambar 4.5 jumlah cluster yang optimal adalah tiga cluster. Setelah mendapatkan jumlah cluster yang terbaik, selanjutnya adalah pusat cluster awal (centroid).

\section{H. Clustering K-means}

Setelah menentukan centroid, maka dilakukan proses clustering menggunakan algoritma k-means. Proses clustering dilakukan melalui aplikasi SIG yang telah dibangun. Proses clustering dimulai dengan memasukkan pusat cluster (centroid) awal ke dalam aplikasi terlebih dahulu. Setelah berhasil memasukkan centroid awal yang selanjutnya adalah memasukkan data yang akan dilakukan clustering, melalui menu import data. Setelah data berhasil diimport dilakukan proses clustering melalui aplikasi SIG. Setelah proses clustering berhasil dilakukan, hasil dari proses clustering tersebut ditampilkan dalam peta spasial. 
Tabel 4.2 Hasil Clustering K-means

\begin{tabular}{|c|c|c|c|c|c|c|}
\hline $\begin{array}{c}\text { Id } \\
\text { Reklame }\end{array}$ & $\begin{array}{c}\text { Jarak } \\
\text { dengan } \\
\text { Traffic } \\
\text { light } \\
\end{array}$ & $\begin{array}{l}\text { Jarak } \\
\text { dengan } \\
\text { Pasar }\end{array}$ & $\begin{array}{c}\text { Volume } \\
\text { Kendaraan }\end{array}$ & Kecamatan & $\begin{array}{c}\text { Jumlah } \\
\text { Pajak } \\
\text { Reklame } \\
\text { (Rp) / Tahun }\end{array}$ & Cluster \\
\hline 330 & 0,26 & 10,100 & 1105,900 & Kajen & $4,276,800$ & Cluster 1 \\
\hline 333 & 0,078 & 765,400 & 2351,900 & Kedungwuni & $4,276,800$ & Cluster 1 \\
\hline 334 & 1,006 & 162,200 & 2351,900 & Kedungwuni & $4,276,800$ & Cluster 1 \\
\hline 337 & 0,108 & 98,200 & 1794,500 & KarangAnyar & $4,276,800$ & Cluster 1 \\
\hline 338 & 0,441 & 1435,400 & 1105,900 & Kesesi & $4,276,800$ & Cluster 1 \\
\hline 339 & 0,238 & 2489,200 & 1647,600 & Sragi & $4,276,800$ & Cluster 1 \\
\hline 343 & 0,02 & 250,300 & 1105,900 & Kajen & $3,888,000$ & Cluster 1 \\
\hline 345 & 0,134 & 404,200 & 1105,900 & Kajen & $3,888,000$ & Cluster 1 \\
\hline 347 & 0,878 & 34,200 & 2351,900 & Kedungwuni & $4,276,800$ & Cluster 1 \\
\hline 349 & 0,644 & 117,200 & 1647,600 & Bojong & $3,888,000$ & Cluster 1 \\
\hline 350 & 0,287 & 17,100 & 1105,900 & Kajen & $3,118,500$ & Cluster 1 \\
\hline 351 & 0,612 & 149,700 & 1647,600 & Bojong & $4,276,800$ & Cluster 1 \\
\hline 352 & 2,547 & 1785,600 & 1647,600 & Bojong & $5,760,000$ & Cluster 1 \\
\hline 356 & 1,695 & 851,600 & 2351,900 & Kedungwuni & $4,276,800$ & Cluster 1 \\
\hline 357 & 0,842 & 2,000 & 2351,900 & Kedungwuni & $4,276,800$ & Cluster 1 \\
\hline 358 & 0,841 & 2,700 & 2351,900 & Kedungwuni & $8,100,000$ & Cluster 1 \\
\hline 360 & 0,229 & 239,300 & 94,500 & KarangAnyar & 0,000 & Cluster 1 \\
\hline 361 & 0,829 & 14,100 & 2351,900 & Kedungwuni & 729,000 & Cluster 1 \\
\hline 362 & 0,84 & 3,400 & 2351,900 & Kedungwuni & $3,888,000$ & Cluster 1 \\
\hline 363 & 0,249 & 1,000 & 1105,900 & Kajen & $4,276,800$ & Cluster 1 \\
\hline 364 & 0,762 & 0,700 & 1647,600 & Bojong & $4,276,800$ & Cluster 1 \\
\hline 365 & 0,138 & 407,600 & 1105,900 & Kajen & $8,553,600$ & Cluster 1 \\
\hline 366 & 0,238 & 2488,900 & 1647,600 & Sragi & $8,553,600$ & Cluster 1 \\
\hline 369 & 0,844 & 0,400 & 2351,900 & Kedungw & 70,000 & Cluster 1 \\
\hline 373 & 0,84 & 4,000 & 2351,900 & Kedungwuni & $3,888,000$ & Cluster 1 \\
\hline 374 & 0,848 & 4,800 & 2351,900 & Kedungwuni & $3,888,000$ & Cluster 1 \\
\hline 331 & 0,073 & 9,200 & 3261,400 & Wiradesa & $5,184,000$ & Cluster 2 \\
\hline 332 & 0,049 & 14,100 & 3261,400 & Wiradesa & $2,430,000$ & Cluster 2 \\
\hline 344 & 0,051 & 12,200 & 3261,400 & Wiradesa & $2,916,000$ & Cluster 2 \\
\hline 353 & 0,168 & 04,500 & 3261,400 & Wiradesa & $8,910,000$ & Cluster 2 \\
\hline 354 & 0,99 & 123,000 & 3991,600 & Tirto & $4,276,800$ & Cluster 2 \\
\hline 359 & 0,066 & 3,000 & 61,400 & Wiradesa & $16,200,000$ & Cluster 2 \\
\hline 367 & 0,997 & 116,200 & 3991,600 & Tirto & $17,820,000$ & Cluster 2 \\
\hline 368 & 1,07 & 1133,500 & 3261,400 & Wiradesa & $2,430,000$ & Cluster 2 \\
\hline 371 & 0,025 & 38,600 & 3261,400 & Wiradesa & $5,184,000$ & Cluster 2 \\
\hline 372 & 1,024 & 88,400 & 3991,600 & Tirto & $3,888,000$ & Cluster 2 \\
\hline 375 & 0,059 & 4,700 & 3261,400 & Wiradesa & $4,276,800$ & Cluster 2 \\
\hline 335 & 2,213 & 7429,800 & 1794,500 & Wonopringgo & $4,276,800$ & Cluster 3 \\
\hline 336 & 0,322 & 4894,500 & 1794,500 & Wonopringgo & $4,276,800$ & Cluster 3 \\
\hline 340 & 0,025 & 7435,000 & 2351,900 & Doro & $4,276,800$ & Cluster 3 \\
\hline 346 & 0,203 & 5013,800 & 1794,500 & Wonopringgo & $3,888,000$ & Cluster 3 \\
\hline 348 & 0,344 & 4872,000 & 1794,500 & Wonopringgo & $3,888,000$ & Cluster 3 \\
\hline 355 & 0,959 & 3558,600 & 2351,900 & Buaran & $4,276,800$ & Cluster 3 \\
\hline 370 & 0,385 & 4831,600 & 1794,500 & Wonopringgo & $7,776,000$ & Cluster 3 \\
\hline
\end{tabular}

Berdasarkan Gambar 4.6 bahwa hasil clustering menggunakan algoritma $k$-means di dapatkan 3 cluster. cluster 1 ditunjukkan dengan marker berwarna merah, cluster 2 ditunjukkan dengan marker berwarna hijau dan cluster 3 ditunjukkan dengan marker berwarna biru. Rincian hasil clustering $k$ means ditunjukkan pada tabel 4.2.

\section{Pembahasan}

Dari hasil analisis, cluster 2 merupakan cluster yang mempunyai rata - rata penerimaan pajak reklame yang paling tinggi daripada cluster yang lain. Reklame yang ada pada cluster ini berada di Kecamatan Wiradesa dan Tirto, dimana keduanya merupakan kecamatan di Kabupaten Pekalongan yang dilewati Jalur Pantura. Kecamatan yang dilewati jalur pantura mempunyai korelasi dengan tingginya besaran pajak reklame di Kabupaten Pekalongan. Cluster 2 merupakan cluster yang mempunyai rata - rata kedekatan dengan pasar dan traffic light yang paling dekat, sehingga dapat disimpulkan bahwa kedekatan dengan pasar dan traffic light mempunyai korelasi dengan tingginya besaran pajak reklame di Kabupaten Pekalongan. Begitu pula untuk volume kendaraan, yang paling tinggi adalah cluster 2 , sehingga bisa disimpulkan bahwa volume kendaraan mempunyai korelasi dengan tingginya besaran pajak reklame di Kabupaten Pekalongan.

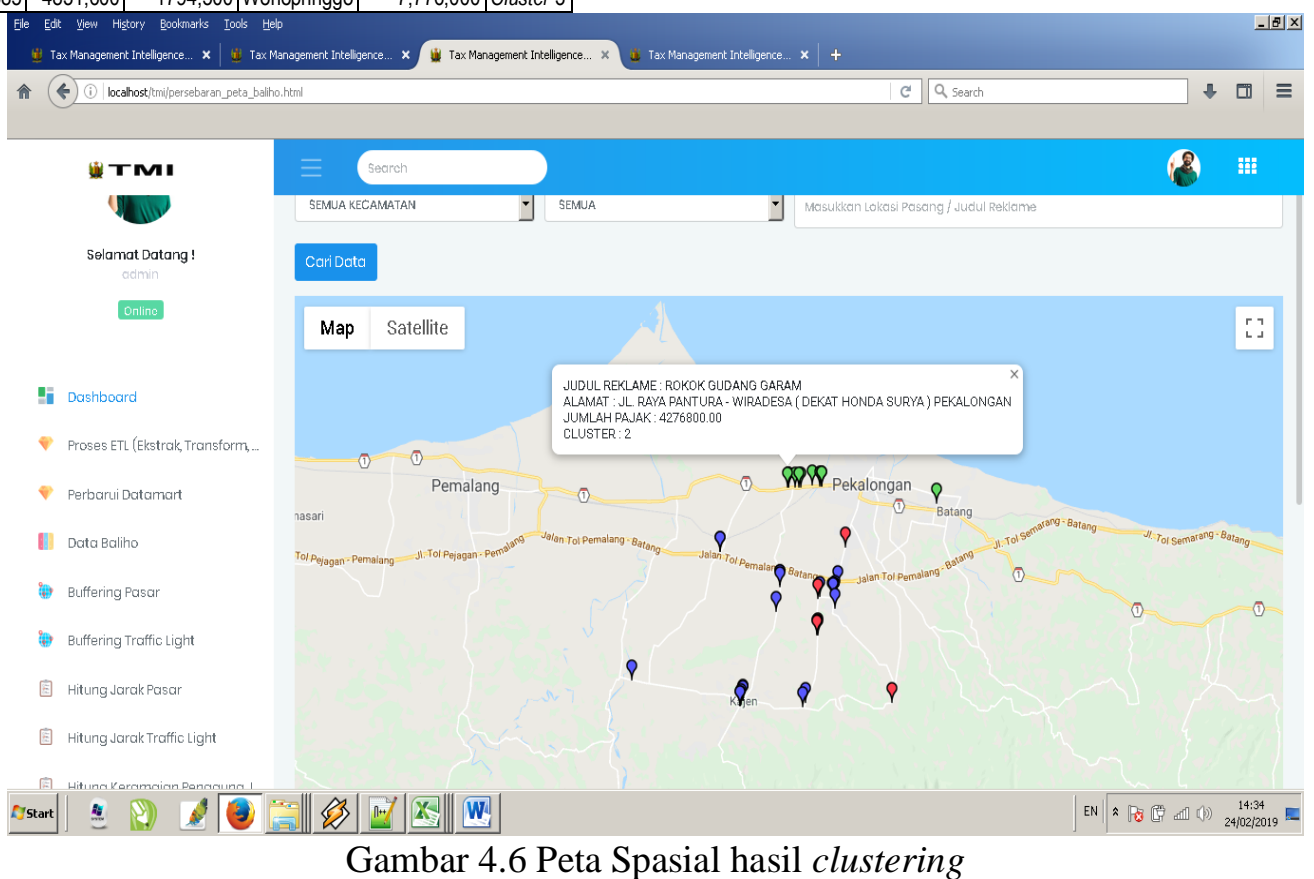


Berdasarkan penelitian dapat diketahui bahwa di Kabupaten Pekalongan terdiri dari 19 Kecamatan, dimana dari 19 kecamatan tersebut ada 8 kecamatan yang tidak ada pasar dengan jenis pasar umum. Berdasarkan pengolahan data, reklame dengan jenis baliho tersebar pada kecamatan yang mempunyai pasar umum. Ada 1 (satu) kecamatan dimana pada pasar tersebut tidak ada pasar umumnya namum ada reklame balihonya, hal tersebut terjadi karena kecamatan tersebut merupakan perbatasan antara Kabupaten Pekalongan dan Kota Pekalongan, dimana diperbatasan tersebut ada pasar yang merupakan kawasan Pekalongan Kota. Berdasarkan kondisi tersebut dapat disimpulkan bahwa persebaran reklame baliho dapat dikaitkan dengan adanya pasar umum pada Kecamatan. Dari hasil clustering dapat dihasilkan pula bahwa sebagian besar reklame tersebar pada kecamatan yang ada traffic lightnya. Ada beberapa kecamatan dimana pada kecamatan tidak ada traffic lightnya namun ada reklamenya, hal itu terjadi karena pada kecamatan tersebut ada pasar umumnya.

\section{KESIMPULAN}

Analisis spasial persebaran reklame dengan metode clustering, telah berhasil dilakukan melalui sistem yang dibangun. Sistem dibangun untuk membantu penulis dalam melakukan pengumpulan data (terutama data spasial), penyeragaman data, dan melakukan proses clustering. Algoritma yang diterapkan dalam clustering adalah algoritma k-means. Setelah melakukan beberapa hal terkait dengan perancangan, pengujian dan analisis maka diperoleh beberapa kesimpulan berikut ini:

1. Kecamatan yang dilewati jalur pantura mempunyai korelasi dengan tingginya besaran pajak reklame di Kabupaten Pekalongan, hal ini dapat dilihat padacCluster 2, dimana pada cluster 2 merupakan cluster yang mempunyai rata rata besaran pajak yang paling tinggi. Reklame yang berada pada cluster ini semuanya berada pada kecamatan yang dilewati Jalur Pantura (Kecamatan Tirto dan Wiradesa).

2. Kedekatan dengan pasar dan traffic light mempunyai korelasi dengan tingginya besaran pajak reklame baliho di Kabupaten Pekalongan. Hal ini terlihat pada cluster 2, dimana cluster ini mempunyai rata - rata besaran pajak yang paling tinggi dan reklame pada cluster ini mempunyai kedekatan dengan pasar dan traffic light yang paling dekat.

3. Pada cluster 2 mempunyai rata - rata Volume kendaraan yang paling tinggi, jika dibandingkan dengan cluster 1 ataupun cluster 3. sehingga bisa dikatakan bahwa volume kendaraan mempunyai korelasi dengan tingginya besaran pajak reklame di Kabupaten Pekalongan.

4. Reklame Baliho di Kabupaten Pekalongan, sebagian besar tersebar pada kecamatan yang ada pasar umumnya. Ada 1 kecamatan dimana pada pasar tersebut tidak ada pasar umumnya, namun terdapat terdapat reklamenya. Setelah diamati ternyata pada kecamatan tersebut merupakan perbatasan dengan daerah lain, dimana pada perbatasan tersebut terdapat pasar umum yang merupakan wilayah dari daerah lain.

\section{REFERENSI}

[1] Republik Indonesia. 2004. UndangUndang Republik Indonesia Nomor 32 Tahun 2004. Lembaran Negara RI Tahun 2004, No. 125. Sekretariat Negara. Jakarta.

[2] Kabupaten Pekalongan. Peraturan Kabupaten Pekalongan Nomor 10 Tahun 2010 tentang Pajak Daerah. Lembaran Daerah Kabupaten Pekalongan Tahun 2012 Nomor 6 Tambahan Lembaran Daerah Kabupaten Pekalongan Nomor 27

[3] Kabupaten Pekalongan Dalam Angka. 2017. Badan Pusat Statistik Kabupaten Pekalongan

[4] Peraturan Bupati Pekalongan Nomor 50 Tahun 2015 Tentang Penyelenggaraan Reklame. Kajen 31 Desember 2015

[5] Ruliansyah, Andri (dkk). 2017. Analisis Sebaran Demam Berdarah Dengue di Kota Tasikmalaya Tahun 2011-2015. Aspirator, 9(2), pp. 85-90

[6] Widyaningrum, Dyah, Sudarsono, Bambang, dan Nugraha, Arief Laila . 2017. Analisis Sebaran Reklame Billboard Terhadap Lokasi dan Nilai Pajak Reklame Berbasis Sistem Informasi Geografis. Jurnal Geodesi Undip, Volume 6, No.1

[7] Ruswanto, Bambang. 2010. Analisis Spasial Sebaran Kasus Tuberkulosis 
Paru Ditinjau Dari Faktor Lingkungan Dalam Dan Luar Rumah di Kabupaten Pekalongan. Tesis. Pascasarjana Universitas Diponegoro Semarang

[8] Nasari, F., Darma, S., \& Informasi, S. (2015). Penerapan $K$-means Clustring Pada Data Penerimaan Mahasiswa Baru, 6-8.

[9] Metisen, Benri Melpa dan Herlina Latipa Sari.2015. Analisis Clustering Menggunakan Metode K-means Dalam Pengelompokkan Penjualan Produk Pada Swalayan Fadhila. Jurnal Scientific Pinisi, Volume 2, Nomor 2, hlm. 92-96

[10] Rosmini, Fadlil Abdul dan Sunardi.2018.Implementasi Metode $K$ Means dalam Pemetaan Kelompok Mahasiswa Melalui Data Aktivitas Kuliah. IT Journal Research and
Development Vol.3, No.1. eISSN:2528-4053.

[11] Hadi, Alfian Futuhul, Sa'diyah Halimatus, dan Sumertajaya I Made. 2007. Penanganan Ketaknormalan Data Pada Model AMMI dengan Transformasi Box-Cox. Jurnal ILMU DASAR, Vol. 8 No. 2, Juli 2007 : 165174

[12] Charrad, Malika, Ghazzali Nadia, Boiteau Veroniqe, dan Laval Universite. 2014. NbClust: An R Package for Determining the Relevant Number of Clusters in a Data Set. Journal of Statistical Software. Volume 61 , Issue 6. 